実験条件として浴塩組成 $\mathrm{KCl}: \mathrm{NaCl}=2: 1$ (モル比) $50 \mathrm{~g}, \mathrm{Al} ; 0.5 \mathrm{~g}, \mathrm{TaCl}_{5}, \mathrm{NbCl}_{5} 2,5,10 \mathrm{~g}$ のそれぞれ の場合, 温度; $850^{\circ} \mathrm{C}$, 時間; $90 \mathrm{~min}$ で行なつた。結果 を生成状態からみると，2g の場合が粉末状生成物と末 反応の $\mathrm{Al}$ よりなり，5g の場合は粉末状生成物(金属), 粒状生成物 (合金部)，末反応の Al とからなり，10 g の場合は一様な粒状生成物からなつている。反応の点か らみると濃度が低い場合 $(2 \mathrm{~g})$ には $\mathrm{Ta}, \mathrm{Nb}$ の生成反 応が主に起こり濃度が高い場合 $(10 \mathrm{~g})$ 飞は，合金生成反 応が主に起こると考号られるしたがつて濃度が低い場 合には収量は低いが純度が高い金属を得ることができ濃 度の高い場合には，純度は比較的よくないが収量がよく なるということから適当な濃度に調整することにより生 成状態が二様でしかも純度の高い金属を得ることができ ると推定される。

\section{4. 総括}

1) $\mathrm{KCl}-\mathrm{NaCl}$ 系溶融塩中で $\mathrm{Al}$ により $\mathrm{TaCl}_{5}$, $\mathrm{NbCl}_{5}$ を還元して $\mathrm{Ta}, \mathrm{Nb}$ をくる場合, 浴塩組成
$\mathrm{KCl}: \mathrm{NbCl}=2: 1$ (モル比) $50 \mathrm{~g}, \mathrm{Al} ; 0.5 \mathrm{~g}, \mathrm{TaCl}_{5}$, $\mathrm{NbCl}_{5}$ 各 $5 \mathrm{~g}$, 温度; $850^{\circ} \mathrm{C}$, 時間; $90 \mathrm{~min}$ で $\mathrm{Ta}$, $\mathrm{Nb}$ の収率それぞれ $64.7 \%$ ，56.3\%で純度は約 $98.8 \%$ である。

2） $750^{\circ} \mathrm{C}$ 一の場合収率は $\mathrm{Ta} ; 32.3 \% ， \mathrm{Nb} ; 40.0 \%$ となり $850^{\circ} \mathrm{C}$ の場合と比較して収率は低下するが，純 度は山がつて約 $99.5 \%$ むのが得られた。

3) 反応生成物の $\mathrm{X}$ 線回折により $\mathrm{TaCl}_{5}+\mathrm{Al}$ と $\mathrm{Nb}$ $\mathrm{Cl}_{5}+\mathrm{Al}$ との反応に招いて直接 $\mathrm{Ta}, \mathrm{Nb}$ が生成する反 応と，中間生成物として Ta-Al 合金， $\mathrm{Nb}-\mathrm{A} .1$ 合金が でき，これがそれぞれ $\mathrm{TaCl}_{5}, \mathrm{NbCl}_{5}$ と反応して単金 属が生成する反応が起こることが明らかになつたが，さ らに浴塩中に括ける $\mathrm{TaCl}_{5}, \mathrm{NbCl}_{5}$ の濃度が低い場合 (2 g ) には $\mathrm{Ta}, \mathrm{Nb}$ の生成する反応が怙こり，濃度が 高い場合 $(10 \mathrm{~g})$ には合金生成反応が打きることが確め られた。したがつて以上の結果から $\mathrm{TaCl}_{5}, \mathrm{NbCl}_{5}$ の 浴塩中の濃度, 温度, 時間, A.l 量を調整することによ り生成状態が一様で，Al 含有量の少ない純度の高い

Ta，Nbを得ることができると思われる。

\title{
1407 溶融塩電解法によるボロンの製造
}

\author{
東京大学生産技術研究所講師 \\ 金属材料技術研究所第 5 部・工博
}

\section{1. 緒言}

1962年度春季研究発表講演会に拈いて，KCl-KF一 $\mathrm{KBF}_{4}$ 系浴の電解ならびに $\mathrm{BCl}_{3}$ の $\mathrm{Zn}$ 還元によるボ ロンの製造法について報告したが，その後電解法につい ては若干の補足的な基礎実験と新しい浴組成についての 検討を行なつて，2,3 の興味ある結果を得たので簡単に 報告する。

\section{2. 電解浴の状態図}

ボロンの製造に有望と考えられる電解浴の基本的組成 としては, 従来の実験結果からは $\mathrm{KBF}_{4}-\mathrm{KCl}, \mathrm{KBF}_{4}-$ $\mathrm{B}_{2} \mathrm{O}_{3}, \mathrm{KF}-\mathrm{KCl}-\mathrm{B}_{2} \mathrm{O}_{3}$ 系などが挙げられる。後述の電 解実験でわれわれは, $\mathrm{KBF}_{4}-\mathrm{KCl}$ 系の $\mathrm{KCl}$ の全部ま たは一部を $\mathrm{KI}$ で置換した浴を用い好結果を得たが， $\mathrm{KBF}_{4}$ にアルカリハライドあるいは $\mathrm{B}_{2} \mathrm{O}_{3}$ を配した系 についての状態図についてはほとんど報告がないので， 全熱分析法による実験を行なつた。なお $\mathrm{B}_{2} \mathrm{O}_{3}$ を含む 浴についての結果と示差熱分析法による精密実験につい ては今回は触れない。

試料としては $\mathrm{KBF}_{4}, \mathrm{KF}, \mathrm{KCl}, \mathrm{KI}\left(\mathrm{KBF}_{4}\right.$ は試薬 1 級，その他は特級）を真空乾燥したものを用いた。円 筒状の透明石英容器内に試料約 $20 \mathrm{~g}$ の入つた白金ルッボ またはグラスカーボンルッボを置き，上方より $\mathrm{Pt}-\mathrm{Pt}$ $\mathrm{Rh}$ 熱電対を裸のまま直接試料内に入れ, 電気炬で溶融 後熱分析を行なつた。雾囲気には脱湿脱酸したアルゴン を用い，実験後試料中の $\mathrm{Cl}^{-}, \mathrm{I}^{-}$を定量して $\mathrm{KCl}$, KI 換算して浴組成を求め, 最初の組成と比較した。 $\mathrm{F}^{-}$と $\mathrm{BF}_{4}-$ の分離定量は問題点が多い。

(1) $\mathbf{K B F}_{4}-\mathbf{K F} \quad \mathrm{KBF}_{4}, \mathrm{KF}$ の融点はそれぞれ $560^{\circ} \mathrm{C}, 857^{\circ} \mathrm{C}$, 単純共晶系で共晶組成は $\mathrm{KF} 14 \%$ (重 量）共晶温度 $430^{\circ} \mathrm{C}$ で, $\mathrm{KF}$ の融点に比較してかなり

\section{○明石 和夫(正会員)，宩京大学生産技術研究所} 河村 和孝(正会員) 東京大学生産技術研究所

湯瀬 源市 大森 正次
低いところにある。

（2） $\mathbf{K B F}_{4}-\mathbf{K C l}$ (第 1 図）単純な 2 元共晶のよう であるが $\mathrm{KBF}_{4}$ 高濃度側に問題が残る。 $\mathrm{KCl} \cdot 11 \mathrm{KBF}_{4}$ のような錯化合物を予想する例》むめるが，確定的とは い光ない。

(3) $\mathbf{K B F}_{4}-\mathbf{K I}$ (第 2 圀) $\mathrm{KI}$ の融点は $680^{\circ} \mathrm{C}$, 前 2 系と異なり液相線の傾斜はきわめて緩く, $\mathrm{KBF}_{4}$ 側 に極大点がめる。固相線掞よび固相での熱変化が全熱分 析では正確に検出できない。

以上の汪か 3 元系を求めるのに必要な $\mathrm{KCl}-\mathrm{KF}, \mathrm{KF}$

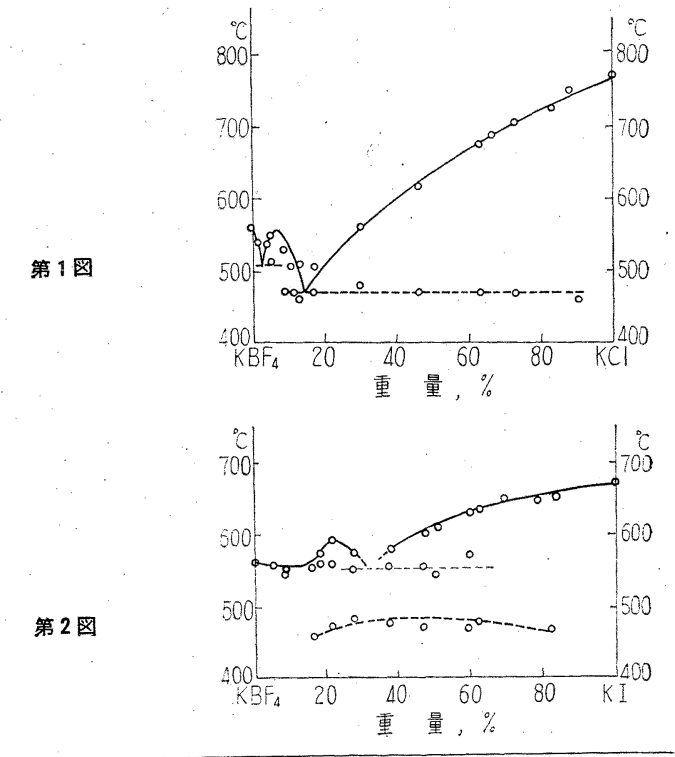

1) G. V. Samsonov : Zhur. Priklad. Khim. 33, 1365 1368 (1960) 
-KI，KCl-KI 各2.元系についても実験を行なつたが，

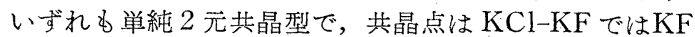
40 重量\% (50モル\%), $600^{\circ} \mathrm{C}, \mathrm{KF}-\mathrm{KI}$ では $\mathrm{KF} 23$ 重 量\% (50モル\%), $555^{\circ} \mathrm{C}, \mathrm{KCl}-\mathrm{KI}$ では $\mathrm{KCl} 29$ 重量 \% (50モル\%), $601^{\circ} \mathrm{C}$ であつた。 $\mathrm{KBF}_{4}-\mathrm{KI}$ を除いて 各系とも固溶度は注とんどないと思われる。

(4)，KBF-KCl-KF $\mathrm{KBF}_{4}-\mathrm{KCl}$ 系の電解に扣け る全反応は， $2 \mathrm{KBF}_{4}+6 \mathrm{KCl} \rightarrow 2 \mathrm{~B}+3 \mathrm{Cl}_{2}+8 \mathrm{KF}^{2}$ ) るい は $4 \mathrm{KBF}_{4}+2 \mathrm{KCl} \rightarrow 4 \mathrm{~B}+6 \mathrm{KF}+5 \mathrm{~F}^{2}+\mathrm{Cl}_{2}{ }^{3}$ であるとさ れ，いずれにしても浴中に $\mathrm{KF}$ が蓄積し結局 2 元系から 出発しても 3 元系の浴を電解することになるので, この 種の系について調べる必要がある。実験結果から $\mathrm{KBF}_{4}$ $30 \%, \mathrm{KF} 30 \%, \mathrm{KCl} 60 \%$ 近辺に極大点 (約700 $\mathrm{C}$ ) が あるようである。

(5) $\mathbf{K B F}_{4}-\mathbf{K C l}-\mathbf{K I} \mathrm{KCl}, \mathrm{KI}$ 高濃度側には錯化 合物のようなものは認められない。 $\mathrm{KBF}_{4}$ 高濃度側に問 題があり, 状態図は複雑となる。

\section{3. 分解電圧の測定}

溶融塩たと光ば塩化物 $\mathrm{MCl}_{n}$ の分解電圧を決定する には $\mathrm{M}^{n+} / \mathrm{MCl}_{n} / \mathrm{Cl}_{2}$ (graphite) のような可逆電池の 起電力を測定すれ桨よいが，ボロン電解浴のよ5に $\mathrm{Cl}^{-}$ 以外に, $\mathrm{F}^{-}, \mathrm{I}^{-}, \mathrm{BF}_{4}$-などを含む混合塩では塩素照 合極を用いることができず可逆電池形成は困難なので 3 極法により電流電圧曲線を求めた。 3 本の同質同大の黑 鉛棒を用い，2本を陰陽両極，1本を中性極として両極 間に電圧（ポテンショメータで精密に測定）を加えつつ 電流の增加を見る。塩容器には不浸透性グラスカーボン ルッボ (内径 $80 \mathrm{~mm}$, 高さ $100 \mathrm{~mm}, 500 \mathrm{cc}$ 程度の浴を 入れる), ふんい気は脱湿脱酸したアルゴンを用いた。

（1） $\mathbf{K C l}-\mathbf{K B F}_{4}$ 分解電圧と濃度の関係を第 3 図 に示した。 $\mathrm{KBF}_{4}$ 単独の場合陰極側の電流電位曲線の変 化がやや不明確で，2個の直線部が得られ，それぞれに 相当する電圧值は $1.79 \mathrm{~V}, 2.24 \mathrm{~V}$ であつた。混合塩の 分解電圧值は $\mathrm{KCl}, \mathrm{KBF}_{4}$ 単塩にくらべて著しく低い ので, かなりの復極值の存在が考えられる。この系の電 解機棈としては徉来院極に最初 $\mathrm{K} か ゙$ 析出し, 次に $\mathrm{K} に よ$ り $\mathrm{KBF}_{4}$ が還元されてBが生成すると考えられ，それ を裹づける実験事実もある。還元反応が $3 \mathrm{~K}+\mathrm{KBF}_{4}=$ $4 \mathrm{KF}+\mathrm{B}$ であれば, この反応の $\Delta G$ 值より計算した復 極值は約 $0.9 \mathrm{~V}$ に相当する。陽極側では $\mathrm{Cl}^{-}$のみが放 電するといら考方からすると第一次的には $\mathrm{KCl}$ が電 解されることになるが，陽極ガス中には $\mathrm{F}_{2}$ も認められ るので問題がある。 $\mathrm{F}_{2}$ は陽極の炭素と反応して $\mathrm{CF}_{4}$ を

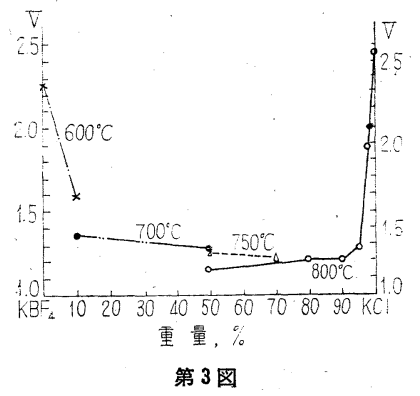

2). H. S. Cooper: U. S. Pat. 2,918, 417 Dec. 22 (1959)

3) G. T. Miller: J. Electrochem. Soc, 106, 815 818 (1958)

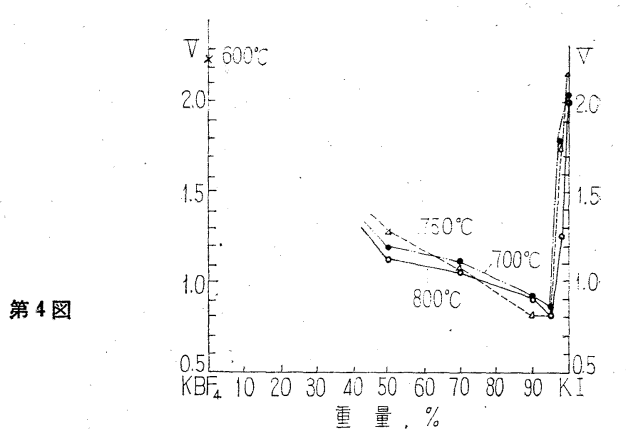

生成するので，この復極值も考えられるが，いずれにし ろ混合塩の分解電圧值が相当低くなつていることはうな づける。

な拉 $\mathrm{MCl}_{n}$ の分解電圧值 $E=E_{0}-\frac{R T}{n F} \cdot \ln \frac{a_{\mathrm{M} \mathrm{Cl}}}{a_{\mathrm{M} a_{\mathrm{Cl} 2}{ }^{n / 2}}}$ ( $a$ は活量) に扎いて, $a_{\mathrm{M}}=1, a_{\mathrm{Cl}_{2}}=1, a_{\mathrm{MCl} 1}=N_{\mathrm{MC} 1}(N$ はモル分率）として $-\frac{R T}{n F} N_{\mathrm{MC1}}$ の值を計算してみると， 同組成ならば温度が $100^{\circ} \mathrm{C}$ らがつても $0.00 \mathrm{nV}$ 程度， 同温度では組成が50モル\%近く違つても $0.0 \mathrm{nV}$ 程度の 差しか生じないので，1V 程度の分解電压值の減少に対 してはほとんぞ無視できることがわかる。

（2） $\mathbf{K B F}_{4}-\mathbf{K I}$ 分解電生と濃度の関係は第 4 図に 示した。この系も混合塩の分解電圧は単塩にくらべて著 しく小さく，㓌極側では前系と同じ機構でのB析出の復 極作用があると考兄られる。電解時（後述）に陽極側か ら多量の $\mathrm{I}_{2}$ の生成が認められ，一次的に $\mathrm{KI}$ が電解さ れていると推定される。 $\mathrm{KI}$ の分解電圧值は $\mathrm{KCl}$ のそ れよりかなり低いことにも注意したい。

\section{4. ボロンの電解採取}

電解浴として $\mathrm{KBF}_{4}-\mathrm{KCl}$ 系の代りに $\mathrm{KBF}_{4}-\mathrm{KI}$ 拉

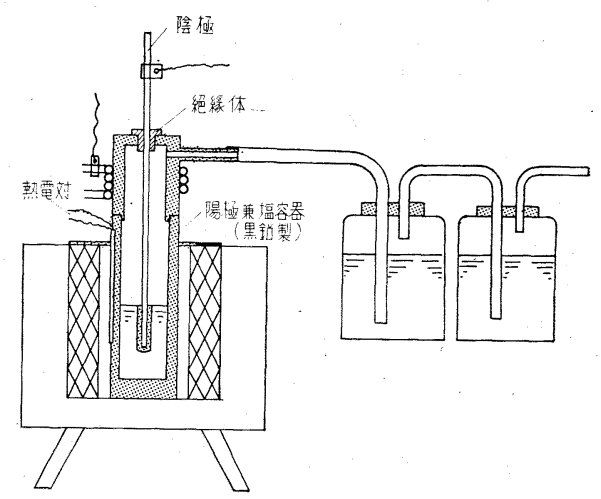

第 5 図

\begin{tabular}{|c|c|c|c|c|c|c|c|c|c|c|c|}
\hline \multicolumn{12}{|c|}{ 第 1 表 } \\
\hline 番 & \multicolumn{4}{|c|}{ 電解浴組成重量 \% } & \multirow{2}{*}{$\begin{array}{c}\text { 温度 } \\
{ }^{\circ} \mathrm{C}\end{array}$} & \multirow{2}{*}{$\begin{array}{c}\text { 電流 } \\
\mathrm{A}\end{array}$} & \multirow{2}{*}{$\begin{array}{c}\text { 電 纴 } \\
\mathrm{V}\end{array}$} & \multirow{2}{*}{$\begin{array}{l}\text { 電流密度 } \\
\mathrm{A} / \mathrm{cm}^{2}\end{array}$} & \multirow{2}{*}{$\begin{array}{c}\text { 電流 } \\
\text { 効率 } \\
\%\end{array}$} & \multirow{2}{*}{$\mid$\begin{tabular}{|c|} 
純口度 \\
$\%$
\end{tabular}} & \multirow{2}{*}{ 析出状態 } \\
\hline 号 & $\mathrm{KBF}_{4}$ & $\mathrm{KI}$ & $\mathrm{KCl}$ & $\mathrm{B}_{2} \mathrm{O}_{3}$ & & & & & & & \\
\hline 1 & 10 & 90 & & & 810 & & $|2.4 \sim 3.0|$ & 1 & 45 & 96.3 & 樹枝状金属光沢 \\
\hline 2 & 30 & 70 & & & 80 & & 2.3 & 1 & $\begin{array}{l}67 \\
67 x-10\end{array}$ & 95.8 & 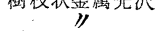 \\
\hline 3 & 30 & 70 & & & 80 & & & 1 & 60 & 97.4 & "1" \\
\hline 4 & $\begin{array}{r}13.9 \\
15\end{array}$ & 36.6 & 49.5 & & 800 & 20 & $2.7 \sim 3.4$ & $\begin{array}{r}1 \\
0.5\end{array}$ & $\begin{array}{l}46 \\
80\end{array}$ & 92.4 & "I" \\
\hline $\begin{array}{l}5 \\
6\end{array}$ & $\begin{array}{r}15 \\
5\end{array}$ & $\begin{array}{l}30 \\
15\end{array}$ & $\begin{array}{l}55 \\
75\end{array}$ & 5 & $\begin{array}{l}810 \\
810\end{array}$ & $0 \sim 30$ & $\left|\begin{array}{l}2.2 \sim 3.7 \\
3.6 \sim 3.2\end{array}\right|$ & $\begin{array}{l}0.5 \\
1.5\end{array}$ & $\begin{array}{l}80 \\
74\end{array}$ & $\begin{array}{l}98.1 \\
89.1\end{array}$ & 状" \\
\hline 7 & 5 & 30 & 60 & 5 & 810 & 30 & 3. $3 \sim 2.9$ & 1.1 & 39 & 90.0 & 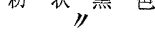 \\
\hline 8 & 10 & 20 & 60 & 10 & 860 & $70 \sim 80$ & $4.2 \sim$ & 2 & 77 & 79.8 & " \\
\hline
\end{tabular}


よび $\mathrm{KBF}_{4}-\mathrm{KI}-\mathrm{KCl}$ 系を選び電解を行なつた。前述の 上らに電解機構は $\mathrm{KBF}_{4}-\mathrm{KCl}$ 系比類促と考光られる。 電解装置は第 5 図に示した。黒鉛るつ潘は外径 $105 \mathrm{~mm}$, 内径 $70 \mathrm{~mm}$, 高さ $300 \mathrm{~mm}$ のむので，これに黑鉛製の蓋 (外径 $105 \mathrm{~mm}$, 高さ $130 \mathrm{~mm}$ ) 老かぶせ, 蓋には排気口 をつけ，ガス捕集装置に導く。蓋の中心絶縁体をとり つけ，これ陰極棒老通す。ルッボ上部または蓋の部分 儿水冷銅管を巻きここれを陽極ターミナルとした。黑鉛 ルツボの酸化を防ぐために鉄製またはステンレス鋼製の 保護ケースを゙使用すると，ルッボの寿俞は長くなるが， ルッボを通して浴の中に Fe が溶けこんで浴を活し, 析 出物の純度を低下させることが従来の実験からわかつた ので，今回はルッボは裸のままとし， Ar または $\mathrm{N}_{2}$ 気 流中に置いて実験した。陰極材は最初直径 $10 \mathrm{~mm}$ の種 々の材料 ( $\mathrm{Fe}, \mathrm{Ni}$ ，モネル，18-8 ステンレス）を用い て試験したが, 電解後析出物中に陰極成分が相当含まれ てくることがわからた。とくに Fe や C r はボライドを 作りやすい。Ni は浴に浸食される量も少なくボライド 作りにくく，乙か子㓌極析出物の上端にのみ集まる傾 向があり分離が比較的容易であつたので，大部分の実験 は $\mathrm{Ni}$ を使用した。直流電源には $\mathrm{Ge}$ 整流器を使用し, 電気量は積算電流計によつて测定した。浴量は約 $1 \mathrm{~kg}$, 20あるいは30Aの定電流電解を行なつた。電解終了後陰 極を引きをげ不活性ガスを通じて析出物を冷却後陰極よ り分離させ, 鉄製乳鉢で砕き水洗, 酸洗, 水洗, アルコ 一几洗浄後減圧乾燥した。

(1) 電解結果 数例を第 1 表に示した。 $\mathrm{B}_{2} \mathrm{O}_{3}$ を少 量添加した場合の例も示した。

（2）考察 一般的に $\mathrm{KBF}_{4}$ の濃度が高い万が電流

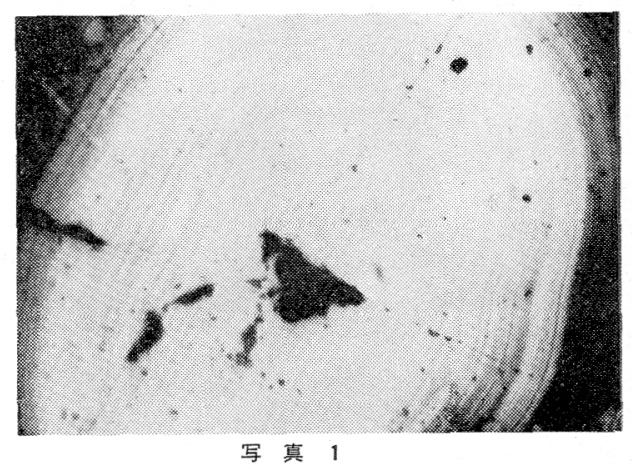

效率(見掛比)は高いが析出物の純度が低くなる。 $\mathrm{KBF}_{4}$ $\mathrm{KI}-\mathrm{KCl}$ 系では陰極電流密度を大にすると析出物の純 度, 電流效率が低下する。 $\mathrm{KBF}_{4}(15)-\mathrm{KI}(30)-\mathrm{KCl}(55)$ の浴栄 $800^{\circ} \mathrm{C}$, 陰極電流密度 $0.5 \mathrm{~A} / \mathrm{cm}^{2}$ の条件で電解す れば，電流效率 $80 \%$ 以上で純度 $98 \%$ 以上のBが容易に得 られる。 $\mathrm{KBF}_{4}-\mathrm{KI}$ では $\mathrm{KBF}_{4} 10 \sim 30 \%$, 陰極電流密度 $<2 \mathrm{~A} / \mathrm{cm}^{2}, 800{ }^{\circ} \mathrm{C}$ で電流効率70\%程度で $98 \%$ 純度のBを 得ることができる。析出物が樹枝状で金属光沢をもら硬 いのが特徴で, $\mathrm{B}_{2} \mathrm{O}_{3}$ 拿导浴からの析出物々大きく異 なる。電解浴の分析と捕集した $\mathrm{I}_{2}$ の量から電解時の反 応を推定すると $\mathrm{KBF}_{4}-\mathrm{KI}$ では $\mathrm{KBF}_{4}+2 \mathrm{KI} \rightarrow \mathrm{B}+\mathrm{I}_{2}+$ $3 \mathrm{KF}+1 / 2 \mathrm{~F}_{2}, \quad \mathrm{KBF}_{4}-\mathrm{KI}-\mathrm{KCl}$ では $\mathrm{KBF}_{4}+3 \mathrm{KI} \rightarrow \mathrm{B}+$ $3 / 2 \mathrm{I}_{2}+4 \mathrm{KF}$ となるが，さらに検討を要する。なお $\mathrm{KBF}_{4}$ -KI 系浴から析出したBの顕微鏡組織（倍率 470 , conc $-\mathrm{HNO}_{3}$ 中に 1 時間浸漬) の一例を写真 1 に示した。年 輪状に成長した跡が覗われて面白い。

\section{8 マグネシウムの特殊電解製錬法に関する研究（第 5 報）}

\section{— $200 \mathrm{~A}$ 電解用チタンスラッグ陽極の製造——}

\begin{abstract}
東京大学生産技術研究所教授・工博
東宗大学生産找術研究所讙師
\end{abstract}

\section{江上一郎(正会員) 東京大学生産技術研究所技官}

明石 和夫(正会員) 三菱金属猞業(株)中央研究所
○鈴木 鉄也(正会員) 細田正
1. 緒言

昭和 39 年度全国鉣業大会に扔いては, チタンスラッグ 一炭素質混合陽極による $\mathrm{Mg}$ の電解製錬法について報告 し, 小型極の加圧成型法々強度試験結果, 陽極塩素之陽 極の反応性, 手押し成型中型極による電解結果, 電解炉 の型式とくに陽極導入部の構造などについて述べたが， 中型極についてはさらに原料の配合, 成型法, 焼成法な ぞを検討し，陷の少ない文夫な電極を作り電解を行な ろ必要学認め, 今回の実験を行なつた。

\section{2. 電極の製造}

(1) 原料の種類 チタンスラッグ, コークス, ピッ チ,タール。チタンスラッグの代りにルチルむ試験的に 使用した。分析值(重量％) 第1表に示す。

\section{(2) 原料の配合}
A. スラッグトピッチ十ュークス (100mesh, 200mesh)
B。スラッグ+ピッチ十黒鉛 (300mesh)
C．スラッグ+ピッキータールトコークス(100mesh)

D.ルチル十ピッチ+コークス (100mesh)

ピッチの配合量は原料総量の $11 \%, 12 \%, 13 \%$ と, タールを用いる場合は配合ピッキ量の $20 \%$ タールで置 換した。コークスと黒鉛の添加量は, ピッチとタール中 の固定宸素量を考虑し, 電極中の孷素分が所定\%(接成 後で15\%)になるように決定した。

(3) 原料の混揑 容量 200 の のガス加熱双腕混揑機 (腕の回転数 $35 \mathrm{rpm}, 44 \mathrm{rpm}$ ) を用い，1回に約 $260 \mathrm{~kg}$ の 原料を混揘した。混揘最高温度は $180^{\circ} \mathrm{C}$, 混揑時間は 2 時間とした。

（4）成型 厚さ $50 \mathrm{~mm}$ の鋼板を溶接して作づた断 面 $200 \times 650 \mathrm{~mm}$, 樑さ $350 \mathrm{~mm}$ の型”中に, 同断面の $48 \mathrm{~mm}$ 厚の鋼製底板を入れ，全体を $180 \sim 200^{\circ} \mathrm{C}$ 儿予熱 し，混揑を終つたペースト状原料を約 $36 \mathrm{~kg}$ 装入し， その上に $82 \mathrm{~mm}$ 厚の鋼製押板を置き， $300 \mathrm{t}$ 油圧プレス 機により $30 \mathrm{~min}$ 間加圧し，冷却後型の下に電極を押出 した。電極の寸法は $250 \times 620 \times 100 \mathrm{~mm}$ 前後で岕る。成 型圧は $100 \mathrm{~kg} / \mathrm{cm}^{2}, 200 \mathrm{~kg} / \mathrm{cm}^{2}$ とし, 手押し成型した 極导試験的に製造した。

（5）焼成成型極は鋼製焼成箱 $(580 \times 620 \times 1,800$ 